\title{
Some Aspects of Liability for Nonperformance of Constitutional Justice Authorities Decisions of the Territories in the Russian Federation
}

\author{
Marina Mokoseeva ${ }^{1}$ \\ ${ }^{1}$ Mari State University, RF, Mari El Republic, Yoshkar-Ola city, Russian Federation \\ Correspondence: Marina Mokoseeva, Mari State University, 424000, RF, Mari El Republic, Yoshkar-Ola city, \\ Lenin Square 1, Russian Federation. E-mail: mrn.mksv@gmail.com
}

Received: November 17, 2014 Accepted: December 4, 2014 Online Published: February 25, 2015

doi:10.5539/ass.v11n6p287

URL: http://dx.doi.org/10.5539/ass.v11n6p287

\begin{abstract}
The main objective of the research was the question of the responsibility for failure to decisions of constitutional justice authorities in the federal territories.

The author considers the reasons of nonperformance of decisions of constitutional Justice authorities, discourses about types of responsibility. In the article the positive experience in this problem solving by improvement procuracy's relations is discussed. The author suggests possible ways of solution for nonperformance of decisions of constitutional (statutory) courts in Russian federal territories. Also specific proposals focused on caution judicatum solvi-execution of the constitutional (statutory) courts' decisions-are offered here.
\end{abstract}

Keywords: the constitutional (statutory) court decisions, enforcement of court decisions, nonperformance of decisions, improper decision performance, liability for nonperformance of decision

\section{Introduction}

New Russian judicial system formation is one of the most important goals of the political-legal reforms nowadays. The constitutional judicial authorities take the most important place in democratization of political system, in key reorganization of forms and methods of legal institute work, associated with legal defense and legal interests of citizens. Russian constitutional justice contributes to federalism development, supremacy guarantee both federal Constitution and constitutions (statutes) of Russian territories, consolidation of legal space entity, legal protection and legal personal interests, also advance of mechanism realization "control and balance", when the court system may influence on decisions and acts of legislative and executive authorities, 'balanced their'.

Authorities of constitutional justice are sometimes more effective means of protecting the rights of citizens, rather than the district or the arbitration court (in particular, to resolve disputes about the various social benefits, payments).

However, there are problems of activity in this area in need of theoretical understanding. Urgent problem of the theory and practice of constitutional justice is the problem of nonperformance decisions of constitutional justice authorities. Of course, we can cite many examples of their timely execution, but there are facts of a different kind: the apparent neglect, unreasonable delay in the execution of, attempts to overcome their legal force re-adoption of rules similar declared unconstitutional.

In practice there are following types of nonperformance of decisions of constitutional control authorities at the regional level:

1) unjustified delaying in execution of decisions;

2) the formal and partial execution of decision;

3) the total nonperformance of decision. The third type is met too rare.

The examples of nonperformance decision of constitutional judicial authorities are met also at the federal level. So extra concernment is challenged by the fact of total refusal for decision execution of the Russian Constitutional Court-the decision about employment of art. 389 the Code of Civil Procedure at constitutional-legal sense, which 
has been pointed by the Russian Constitutional Court out-the last supervisory instance of general jurisdiction courts is the Supreme court presidium-concerning the applicant, who has applies for revocation of the official clarification of item 6.7 and 10 of the declaration in the Russian Constitution Court Act \#2-P dated February 2007 (Lukin, 2008).

The arbitration court of the Sverdlovsk region began to justify non-obligatory action for that court instead of compliance the ruling of the Russian Constitutional Court dated December 72006 \#872-O-P, concerning the transfer of municipal property to the territory's property (the Ruling dated on March 11, 2008) (Kryazhkov, 2008).

The key goal of the article was definition and solution of theoretical application problems, concerning the nonperformance of constitutional court (statutory) decisions. Researching this work, we use methods of scientific work such as synthesis, analysis, induction, deduction, modeling, logic and historical methods and etc.

The question, concerning with nonperformance of constitutional justice authorities decisions, was the subject of the work of the following scientists: S. Avakyan, M. Baglaiy, N. Bogdanova, N. Varlamova, N. Vitruk, G. Gadjiev, V. Goshulyak, E. Kozlova, V. Kryazhkov, O. Kutafin, V. Lazarev, M. Mituykov, S. Nesmeyanova, V. Chirkin, U. Shulzhenko and others. But now the mechanism of execution of constitutional courts (statutory court) decisions and prosecution for failure to fulfill these decisions, improper execution or obstruction of execution has not been worked out. The choice of the theme of this research was destined by the urgency of an issue-its theoretical and practical importance, and insufficient elaboration in the scientific literature.

\section{Nonperformance Practice}

An example of delaying decisions execution of constitutional justice is the ruling of the Constitutional court of the Republic of Mari El dated on 25 June 2013 in the case of verification of compliance with the Constitution of the Republic of Mari El-paragraph 3, paragraph 5 of the Regulation of appointment, allocation and retirement pensions payment of prolonged meritorious service for persons holding elective municipal positions and municipal positions of municipal service municipality "Morkinsk municipal district" in connection with the complaint of the citizen G. Khairullina.

The disputed norm of decision that municipal employees being dismissed from municipal service under authority specified in paragraphs 1, 2, 3 and 7 of Article 77, paragraph 3 of Article 81 of the Labor Code of the Russian Federation and paragraph 1 of Part 1 of Article 19 of the Federal Law "On Community Service" have right for prolonged meritorious service if at the time of dismissal, they were entitled to old age retirement pension (disability), and just before dismissal they have positions of municipal service no less than 12 full months. Mrs. G. Khairullina requests to adjudge this regulation being inconsistent to Articles 2, 9, 14 and 19 of the Constitution of the Republic of Mari El this provision.

According to the decision of the inquiry commission by a monthly surcharge to the state pension for persons who hold elective municipal positions and municipal positions of municipal service in the municipality "Morkinsk municipal district" dated on February 17, 2012 Mrs. G. Khairullina was refused to establish a monthly co-payment to the state pension for prolonged meritorious service due to the fact that she had work experience at that position 25 years 5 months 28 days therefore at the time of dismissal from the municipal office position VSL of municipal administration "Zelenogorsk rural settlement" she had no right for old age retirement pension (disability) and immediately before the dismissal she was not working in this post.

The Constitutional court of the Republic of Mari El came to the following conclusion: the interpretation of paragraph 3 enforcer paragraph 5 of the Regulation is supposed to recognize the right for receiving the pensions municipal employees only this category, and it denies that right to provide pensions to persons who have experience of municipal service of not less than 25 years and who were fired from the municipal services before the acquisition to an occupational pension therefore it generates difference in the legal status of municipal employees in different categories without objective and reasonable justification. The contested regulation contains legal uncertainty, allows the possibility of deprivation of the right to a pension for persons with prolonged meritorious service who have experience of municipal service of not less than 25 years and retired from municipal service by their own initiative prior to the acquisition of the right to old age retirement pension (disability), which contravenes the provisions of Articles 2, 19 and 55 (part 3) of the Constitution of the Republic of Mari El.

Based on the above paragraph 3, paragraph 5 of the appointment order, allocation and payment of retirement pensions to persons who holding elective municipal positions and municipal positions of municipal service municipality "Morkinsk municipal district" was recognized as inconsistent to the Constitution of the Republic of Mari El, its Articles 2, 19 and 55 (part 3).

The law-enforcement decision by the case of Mrs. G. Khairullina had to be revised, but it took nearly six months 
for restoration of violated right. The reason for nonperformance of this decision was unwillingness to perform that case by the Head of the municipal administration "Morkinsky District", but the case had no media coverage and no publicity.

We can express the another example of delaying execution constitutional justice authorities decision-this is the act of the Statutory court of Sverdlovsk region dated on May 23, 2000, the court recognized irrelevant provisions of the Charter area municipality "Nizhneturinsky area" establishing procedure early termination of the deputies elected authority of local self-government through a vote of voters reviews, and through a referendum as the violation of federal and provincial law. The same non-constitutional regulations were contained in the Charters of 20 municipalities. Following the publication of the act of the Statutory Court, according to its chairman's data-V. Zadiory, changes were made only in the statutes of 9 municipalities.

An example of the formal implementation of the decisions of the Russian Federation Constitutional Court is the decision of the Constitutional court of the Republic of Komi dated on 15 September 2000 concerning the case about checking the constitutionality of paragraph 10 of Art. 3 and Note 2 paragraph 6 of Article 12 of the Law of the Republic of Komi "About single tax on imputed income for certain types of activities" according to a complaint of the shareholders of LLC "Commission goods". The decision noted that in paragraph 10 of Art. 3 of the law has been interpreted too broadly a conception "retail", including in it also the commission activity, thereby allowing to consider the persons engaged in commission business to a single tax payers, that fact is contrary to the Russian legal system. The State Council of the Republic of Komi was proposed to amend the Law of the Republic concerning "About single tax on imputed income for certain types of activities", bringing it into line with the federal law system.

On November 15, 2000, the State Council of the Komi Republic adopted the Law of the Republic of Komi "Amendments and Additions to the Law "About single tax on imputed income for certain types of activities", paragraph 10 of Art. 3 was expelled. However, the same act of legislation added to Art. 12 part 6, which establishes the base rate for calculating the value-added tax to trade commission contracts with individuals. Thus, the amount of value added tax to the commission of goods has not changed (Gavrusov, 2001).

Thus, the decisions of the constitutional (statutory) courts require actions by the legislative (representative) and executive state authorities, local government, the courts and other law enforcers (Vitruk, 2002, p. 41). Here we see specific examples of nonperformance of constitutional justice. To talk about the methods that allow to make subjects to actively execute the decision of the constitutional control authority, is necessary to identify the causes of non-performance solutions.

\section{Causes of Nonperformance Decisions}

Reasons for improper execution of acts of constitutional jurisdiction are different. According to L. Lazarev, they are: the legal nihilism as process both in a society and in the government, disrespect for the law and order and contradictory processes in the relations between the federal center and the regions, and flawed procedural mechanism for enforcement of constitutional jurisdiction, and sometimes imperfection of these very acts-Advanced presentation of their content, which leads to misunderstandings performers (Lazarev, 2002).

N. Vitruk pointed "weakness, ineffective execution of decisions of the Russian Federation Constitutional Court and the constitutional (statutory) courts in the Russian Federation territories in many cases, is caused not only to the general underestimation of the role and importance of constitutional justice in ensuring legal stability, consolidation of the constitutional system, especially in the qualitative transformation of public failure (lack of sufficient material-financial resources and means, legal nihilism, low legal culture of population), underestimation of the role and importance of constitutional justice, lack of sufficient experience of young constitutional courts, the low prestige of the courts, the instability of the positive trends in the transition period, but also incomplete legislative regulation of the stage of constitutional jurisdiction mechanism ensure that decisions of the Constitutional Court of the Russian Federation to its logical end, to implementation, the lack of a real constitutional and legal responsibility for the non-enforcement of the constitutional courts" (Vitruk, 2002, p. 40).

Undoubtedly, one of the main reasons for nonperformance of constitutional justice decisions is a clear disrespect of these decisions on the part of the society. The problem is in that fact it is not legally established, what are the decisions of the Russian Constitutional Court and the constitutional (statutory) courts and the place they occupy among the sources of law. Therefore there is an ambivalent attitude to these acts. Mr. E. Kolesnikov rightly points out that "the conclusion to classify decisions of the Constitutional Court of the Russian Federation, constitutional (statutory) courts to the sources of law should not be doctrinal or semi-official, based on the opinion of high-position judges or politicians high, but it should be legally fixed" (Kolesnikov, 2001). In addition, the problem of application and enforcement by the courts of the legal positions of the Russian Constitutional Court and 
the constitutional (statutory) courts in the territories of the Russian Federation remains urgent, as contained in decisions in cases of so-called abstract normative control.

Still, the main reason for ignoring the acts of the constitutional control authorities, as already it is noted, is the imperfection of normative-legal regulation. At the federal and regional legislative levels there is no so-called the institute of constitutional responsibility with appropriate penalties. The Federal Constitutional Law "About the Russian Constitutional Court" in Article 81 "Consequences of nonperformance of court decision" contains the following norm: «nonperformance or improper execution or obstacle of decision execution of the Russian Federation Constitutional Court is punished by the federal law." In legislative acts of the territories these elements of law are duplicated. For example, Art. 77 of the Law of the Republic of Mari El dated on March 11, 1997 \#14-Z "About the Constitutional court of the Republic of Mari El".

Another reason for the long-term Implementation of constitutional (statutory) courts of the territories is the lack of economic and financial conditions for their proper execution.

The solution to this problem can be solved by making additions to the budget legislation, where it is necessary to establish a certain amount of funds, the so-called reserve or budgetary mechanism (procedure) that will be used for the execution of decisions (Omarov, 2012), for example, the law of the budget of the territory of the Russian Federation for the next year.

\section{Liability for Nonperformance}

Improper execution of the decision of the constitutional (charter) court is punished by the federal law. For example, Article 315 of the Criminal Code makes it an offense against a public official, a public servant, a municipal employee, as well as employees of state or local government agency, commercial or other organization, providing for penalties of up to two years in prison.

The extreme forms of response are inadequate enforcement of the dissolution of the legislature in the Russian Federation territory, the removal from office of heads of territories in the Russian Federation. It should be noted that the federal law does not currently incorporate measures of constitutional and legal responsibility for these violations to the chambers of the legislative (representative) authorities of political authority (Hajiyev, 2012).

Mr. Z. Ergubaev, a former chairman of the Constitutional court of the Republic of Mari El, believes that "specified in the provisions of the federal legislation on nonperformance of court decisions as the basis for early termination of powers of public authorities of the Russian Federation and local self-government, of course, they are contributed to the strengthening of the single legal space, but they have not solved all range of issues related to the execution of court decisions. Obviously it needs to establish administrative liability for failure to decisions of the courts" (Ergubaev, 2001).

It is proposed to change the Code of Administrative Offences and the territories' laws of Administrative Offences norms establishing liability for failure to solve the constitutional (statutory) court or other judicial act against a public official, a public servant, a municipal employee, as well as employees of state or local government agency, commercial or other organization.

The Law "About the Constitutional court of the Republic of Bashkortostan" (as amended on December 8, 2003) contains a special article "The duty of the state authorities and officials to bring the laws and other normative legal acts of the Republic of Bashkortostan in conformity with the Constitution of the Republic of Bashkortostan in the decision Constitutional court of the Republic of Bashkortostan" (p. 83) (Huseynov \& Pirbudagova, 2007). Referring to this one the State Assembly-Kurultai of the Republic of Bashkortostan within six months after the publication of the decision of the Constitutional court declared unconstitutional the law cancels it, the decision of the State Assembly-Kurultai of the Republic of Bashkortostan, adopts a new law, a new decision or the series of related laws, regulations or modifies and (or) amendments to the law, regulation, recognized in the separate parts. The Government of the Republic of Bashkortostan not later than three months after the publication of the Constitutional court of the Republic makes a Kurultai new draft law of the Republic of Bashkortostan, or series of related draft laws or draft law on amendments and (or) amendments to the law declared unconstitutional in a separate part of it. These bills are considered by Kurultai of the Republic of Bashkortostan in an extraordinary manner.

The President, the Government of the Republic of Bashkortostan not later than one month after publication of the decision of the Constitutional court of the Republic of Bashkortostan cancel the normative legal act by the President of the Republic or the Government of the Republic of Bashkortostan, pass a new normative legal act or make changes and (or) amendments to the normative legal act declared unconstitutional in its separate part. The local governments are also required in the three months to cancel an act or some of its provisions. 
In the next article of the Law of the Republic said that if the territories to which the decision extends over, if at the end of period they don't execute a decision it, then they used the mechanism of responsibility stipulated by the federal law and the laws of the Republic (Goshulyakeva, 2006).

Therefore, you must specify the mechanism of execution of decisions of constitutional (charter) courts, writing it at both the federal and regional levels.

\section{Prosecutorial Control and Monitoring of the Ministry of Justice}

In the statutory court of the Sverdlovsk region there is positive experience in solving this problem. In order to unconditional execution of its decisions, particularly relating to the payment of appropriate compensation and benefits to citizens, was established the close cooperation with prosecutors. Thus, in the course of the working meetings with representatives of the prosecutor's office of the Sverdlovsk region it was agreed on the implementation of control on the part of the execution of the statutory court. It is studied the question of bringing the different kinds of responsibility of officials of a state and local authorities, including the misuse of budget funds allocated for the implementation of the rights of citizens which are protected charter court decisions. Taking in account that the Regulations of the Ministry of Justice of the Russian Federation (item 4.1) provide for monitoring the enforcement of decisions of the Constitutional Court of the Russian Federation with the central administration of the Ministry of Justice of the Sverdlovsk region studied the issue of interaction on the execution of the charter court of Sverdlovsk region (Panteleev, 2012).

The statutory court of the Sverdlovsk region, responding to the complaints of citizens, is not limited to explain the citizen of his right for protection of prosecutors or the court of general jurisdiction. For each of such treatment of a citizen on behalf of the statutory court in the relevant authorities and the prosecutor's office a letter to ensure proper control of the execution of judgments and to assist citizens in exercising their rights was sent.

The practice of interaction with prosecutors exists in the Republic of Mari El. Thus, the decision of the Constitutional court of the RME dated on August 1, 2013, paragraph 2 of the ordinance City District Administration "City of Yoshkar-Ola" dated on August 10, 2012 \#1964 "About Amending Resolution of the Mayor of the city of Yoshkar-Ola on January 30, 2007 \#113 and attributing road section to the road uncommon "was recognized as inconsistent to the Constitution of the Republic of Mari El and due to paragraph 6 of Article 95 repealed. In order to protect the constitutional rights and freedoms of the citizens the Chairman of the Constitutional court of the Republic AM Baranov sent an official letter to the prosecutor of the city of Yoshkar-Ola to take the necessary measures to control the actions of the administration departments of city district "Yoshkar-Ola" to bring the section of the road on the street Volkov in compliance with the requirements established for public roads. This decision has been executed, the road for the citizens of the Republic of Mari El is open.

The Russian Ministry of Justice also monitors the enforcement of the Russian Federation, including for the implementation of decisions of the Constitutional Court of the Russian Federation (the Presidential Decree dated on 20 May 2011). Therefore, the establishment of cooperation with the Russian Ministry of Justice Prosecutors at the regional level is very interesting and promising experience.

Indeed, based on the reports of federal the executive authorities and public authorities of territories of the Russian Federation on the results of monitoring carried out by them in the previous year and other materials, the Russian Ministry of Justice is preparing a draft report to the President of the Russian Federation on the results of monitoring and suggestions to the plan of legislative activities of the Government of the Russian Federation.

\section{Specific Proposals}

To ensure execution of the decisions of the constitutional (statutory) courts, primarily it should be used the mechanism of constitutional and legal responsibilities of the public authorities of the Federation and local authorities stipulated by the federal law of 6 October 1999 \#184-FZ "On general principles of organization of legislative (representative) and executive bodies of territories of the Russian Federation "and 6 October 2003 \#131-FZ" About general principles of organization of local government in the Russian Federation "(Burmistrov, 2011).

A number of changes need to be made in the budget legislation of the territories of the Russian Federation, where it will be necessary to establish a specific budget mechanism (order), which will be used for the execution of decisions of constitutional (statutory) courts of subjects of the Russian Federation.

It will be necessary to amend the Administrative Offences Code of the Russian Federation and regional legislation, and a mechanism of administrative liability for non-performance or improper performance of obstruction of execution of the decision of the constitutional (statutory) court. 
For example, the law of the Republic of Dagestan on 25 April 1996 "About the Constitutional court of the Republic of Dagestan" (Pirbudagova, 2003) provides that "the Constitutional court has the right to impose penalties on the officials and citizens who have shown disrespect to the Constitutional court." The basis for the imposition of a fine for disrespect is non-performance or improper performance of obstruction of execution of the decision of the Constitutional Court. For each case of violation of the Constitutional court has the right to impose fines on citizens in the amount of up to 10 times the minimum wage, and for officials-up to 50 times the minimum wage. And the execution of the decision to impose a fine performs in the manner prescribed by the law.

According to some authors, it is necessary to adopt a separate law about execution of decisions of the constitutional (statutory) courts (Kokotov, 2013). From the point of view of a representative of the President in the Constitutional Court of the Russian Federation M. Krotov expressed at the meeting of the Constitutional Court of 07.10.2008, it needs to take a special law on the implementation of decisions of the Constitutional Court of the Russian Federation. In making this law it could be also solved the problem of passing execution of constitutional (statutory) courts of the Federation. Attempts to adoption of such an act were made in 1992, but then the first reading in the Supreme Soviet of the Russian Federation the bill is not passed.

It seems that the creation of a mechanism of execution of decisions of the constitutional (statutory) courts of the territories of the Russian Federation requires a comprehensive approach to solve this problem. The legislative settlement is made possible by the joint cooperation in the legislative activity of the Constitutional Court of the Russian Federation and representatives of the constitutional (statutory) courts by establishing a joint commission, to our priorities which include the development of the draft Law "On the execution of decisions of the Constitutional Court of the Russian Federation, constitutional (statutory) courts and other bodies of constitutional control of the Russian Federation ", which would contain procedures for constitutional and enforcement proceedings, the mechanism of the constitutional responsibility for failure, improper execution of decisions of constitutional control, customized to the base, possible sanctions. The role of the main guarantor of execution of decisions of the Constitutional Court and the constitutional (statutory) courts should take the President of the Russian Federation and its authorized representatives in the federal districts, respectively (Ovsepyan, 2001).

In turn, the above necessitates the investment of the Prosecutor's Office of the Russian Federation the power to exercise prosecutorial supervision of timely and complete implementation of the decisions of the constitutional (statutory) courts, compliance with legislation in this area.

The Ministry of Justice and the relevant local executive authorities of Russia must be entrusted with the monitoring of normative legal acts declared unconstitutional the appropriate authorities of the constitutional control, as well as monitoring of the laws (Huseynova \& Pirbudagova, 2007).

Of course, in one article to resolve the problem posed is impossible. However, it should be noted that the author did not set out such a task, and tried to assume only likely solutions. On this issue more detais can be found in the research the following authors: Z. Abdurashidova, V. Esenova, A. Kalyak, S. Gavryusova and others.

This article was prepared within the framework of participation in the International competition RHSF-Belarusian Republican Foundation for Fundamental Research (BRFFR) projects of Russian and Belarusian young scientists in 2014 with the financial support of the Russian Humanitarian Science Foundation (project \#14-23-23001). Author appreciates to employees of the Constitutional Court of the Republic of Mari El for their active assistance in the preparation of this article extend.

\section{References}

About the monitoring of law enforcement in the Russian Federation. (2011, May 20). Presidential Decree \#657.

Burmistrov, A. (2011). Validity and mechanism for implementing the decisions of the constitutional (statutory) courts in Russia. State Government and local government, 4, 10-14.

Ergubaev, Z. (2001). In M. A. Mityukova, S. V. Kabysheva, V. K. Bobrova, \& S. E. Andreev (Eds.), About some shortcomings of legal regulation of constitutional (statutory) courts of subjects. Problems of implementation of the federal authorities of state power and state authorities of the Russian Federation, decisions of the Constitutional Court of the Russian Federation and the constitutional (statutory) courts of the subjects of the Russian Federation. Proceedings of the All-Russia meeting, Moscow, March 22, 2001. Moscow.

Gavrus, Y. (2001). In M. A. Mityukova, S. V. Kabysheva, V. K. Bobrova, \& S. E. Andreev (Eds.), The problem of implementation of the decisions of the Constitutional Court of the Russian Federation and the constitutional (statutory) courts of territories of the Russian Federation. Problems of execution of federal authorities and the state authorities of the Russian Federation, decisions of the Constitutional Court of the Russian Federation and the constitutional (statutory) courts of subjects of the Russian Federation, Proc. meeting, 
Moscow, March 22, 2001. Moscow.

Goshulyak, V., Hovrina, L., \& Gevorgkyan, T. (2006). Constitutional justice in the Russian Federation. Moscow.

Hajiyev, G., (2012). Comments to the Federal Constitutional Law "About the Constitutional Court of the Russian Federation." Moscow: Norma.

Huseynov, D., \& Pirbudagova, D. (2007). On the problem of execution of decisions of constitutional (statutory) courts of the territories of the Russian Federation. Government and local self-administration, 9.

Kokotov, A. (2013). Execution of the decisions of the Constitutional Court of the Russian Federation. Journal of Russian law, 5, 90-101.

Kolesnikov, E. (2001). Resolution of the constitutional courts as a source of Russian constitutional law. News of Higher Educational Institutions. Jurisprudence, 2, 36-37.

Kryazhkov, V. (2008). Constitutional culture in the mirror of justice of the Constitutional Court of the Russian Federation. Journal of constitutional justice, 3, 8.

Lazarev, L. (2002). Article: Execution of decisions of the Constitutional Court of the Russian Federation. Russian justice, 9, 19.

Lukin, V. (2008, February 8). Judicial errors. The courts do not respond to complaints about the main human rights activist mass violation of the rights of citizens. The Russian newspaper.

Omarov, S. (2012). Problems of execution by the Federal Assembly of the Constitutional Court of the Russian Federation. Constitutional and municipal law, 1, 52-58.

Ovsepyan, J. (2001). In M. A. Mityukova, S. V. Kabysheva, V. K. Bobrova, \& S. E. Andreev (Eds.), On the interaction of state authorities of the Russian Federation in the field of implementation of the decisions taken by the Constitutional Court of the Russian Federation and the constitutional (statutory) courts of territories of the Russian Federation. Problems of execution of federal authorities and the state authorities of the Russian Federation, decisions of the Constitutional Court of the Russian Federation and the constitutional (statutory) the courts of the Russian Federation. Proceedings of the All-Russia meeting, Moscow, 22 March 2001. Moscow.

Panteleev, V. (2012). Topical issues of modernization and increase the efficiency of constitutional justice in the Russian Federation. Constitutional and municipal law, 3, 46-51.

Pirbudagova, D. (2003). Institute of constitutional control and protection of the constitutional legality in the Republic of Dagestan: The history, theory and practice. Makhachkala.

Questions of the Ministry of Justice of the Russian Federation, Paragraph 4.1 of Art. 7 of the Regulations for the Ministry of Justice of the Russian Federation \#1313, approved Presidential Decree. (2004, October 13). Meeting of the legislation RF, \#42, Art. 4108.

Vitruk, N. (2002). Forum: Enforcement of constitutional courts. Constitutional law: Eastern European view, Moscow, 3, 40.

\section{Copyrights}

Copyright for this article is retained by the author(s), with first publication rights granted to the journal.

This is an open-access article distributed under the terms and conditions of the Creative Commons Attribution license (http://creativecommons.org/licenses/by/3.0/). 